\title{
DAILY DYNAMICS OF MILK QUALITY INDICATORS
}

Vladimir TRUKHACHEV, Faculty of Technological Management, Stavropol State Agrarian University, Zootechnical Lane, 12, Stavropol, Russian Federation, rector@stgau.ru

Sergey OLEYNIK, Faculty of Technological Management, Stavropol State Agrarian University, Zootechnical Lane, 12, Stavropol, Russian Federation, soliynik60@ gmail.com (corresponding author)

Nikolay ZLYDNEV, Faculty of Technological Management, Stavropol State Agrarian University, Zootechnical Lane, 12, Stavropol, Russian Federation, nz-kormlenec@yandex.ru

Dairy cattle breeding is one of the main suppliers of protein and animal fat, it is one of the most important branches of agriculture and plays a primary role in providing adequate nutrition for the population. During the purposeful work on harmonization of the national regulatory framework with international legislation, special attention is paid to scientific developments in the way of full implementation of Russian livestock production in the global trading system.

The recommendations of the International Committee for Registration of Animals (ICAR) (Global Standard..., 2017; Trukhachev et al., 2017) are the methodological basis for the introduction of the generally accepted organizational principles for the recording and evaluation of the productive qualities of animals. One of the stages of this process was implementation in 2015-2017. in the Stavropol State Agrarian University of research projects, especially significant for the agro-industrial complex of the Russian Federation in the direction of ensuring import substitution in animal husbandry (genetic material), which envisage the development of a regional model for the formation and management of highly productive genetic resources for dairy cattle.

The object of the research was cattle (cows) of the North Caucasian population of the Ayrshire breed $(n=550)$, from which, based on the analysis of the materials of the primary zooveterinary records, groups of cows with 3-fold milking were formed to study the daily dynamics of fat and protein content in raw milk samples I, II and III milking, $\mathrm{n}=240$ ) and 2-fold milking (I and II milking - 180 cows). In the process of performing monthly analyzes of the quality of individual milk samples obtained from pedigree cows taken for 2- or 3-fold milking, it was found that a certain pattern is observed in the diurnal dynamics of fat and protein content in milk, which probably has a general biological nature and largely depends on the technological factor - the multiplicity of milking cows, which coincides, basically, with the regularities described in the methodology of the International Committee for Registration of Animals (ICAR).

The nature of the dynamics of the concentration of fat in milk at 2- and 3-fold milking has, though a different mathematical form, but they have a general tendency: the fat in milk for milking cows, as a rule, is $10.77-10.98 \%$ lower, than II and III milking. The variability of the protein concentration in milk during the day is the same as the fat dynamics, though it is less expressed than of fat and accounts $0.88 \%$.

Keywords: milk cows, milk quality, Ayrshire cattle

\section{INTRODUCTION}

A dairy cattle breeding is one of the main suppliers of protein and animal fat, it is one of the most important branches of agriculture and plays a primary role in providing adequate nutrition for the population. During the purposeful work on harmonization of the national regulatory framework with international legislation, special attention is paid to scientific developments in the way of full implementation of Russian livestock production in the global trading system.

The recommendations of the International Committee for Registration of Animals (ICAR) (Global Standard..., 2017; Trukhachev et al., 2017) are the methodological basis for the introduction of the generally accepted organizational principles for the recording and evaluation of the productive qualities of animals. One of the stages of this process was implementation in 2015-2017. in the Stavropol State Agrarian University of research projects, especially significant for the agro-industrial complex of the Russian Federation in the direction of ensuring import substitution in animal husbandry (genetic material), which envisage the development of a regional model for the formation and management of highly productive genetic resources for dairy cattle.

For the material and technical implementation of projects at the University, the Center for the Management of Highly Efficient Genetic Resources for Livestock was established, with the structure: an expert-boniner service; controlassistant service; a reference laboratory for the evaluation of milk quality and a laboratory for genetic control (Trukhachev, et al., 2017). In 2016, the reference laboratory received the official status of the Laboratory for Milk Quality Selection and became a full-fledged participant in the breeding work in the Stavropol Territory.

Copyright (C) 2017 The Authors. Published by Aleksandras Stulginskis University. This is an open-access article distributed under the terms of the Creative Commons Attribution License (CC-BY 4.0), which permits unrestricted use, distribution, and reproduction in any medium, provided the original author and source are credited. 
In the process of performing monthly analyzes of the quality of individual milk samples obtained from pedigree cows taken for 2- or 3-fold milking, it was found that a certain pattern is observed in the diurnal dynamics of fat and protein content in milk, which probably has a general biological nature and largely depends on the technological factor the multiplicity of milking cows, which coincides, basically, with the regularities described in the methodology of the International Committee for Registration of Animals (ICAR) (Global Standard..., 2017).

At the same time, an analysis of specialized scientific and technical literature shows that this direction needs additional research. For example, the attention of many authors focused on studying the variability of the fat level in milk depending on the interval between milkings (Bouloc, et al., 2002; Delorenzo, et al., 1986; Hand, et al., 2004, 2006; Lazenby, et al., 2002; Liu, et al., 2000; Peeters, et al., 2002) and not enough displayed daily dynamics of these indicators.

Thus, the purpose of our research is to study the daily dynamics of milk fat and protein in conditions of varying milking rates and industrial milk production technology.

\section{MATERIALS AND METHODS OF RESEARCH}

The object of the research was cattle (cows) of the North Caucasian population of the Ayrshire breed $(n=550)$, from which, based on the analysis of the materials of the primary zooveterinary records, groups of cows with 3-fold milking were formed to study the daily dynamics of fat and protein content in raw milk samples I, II and III milking, $\mathrm{n}=240$ ) and 2-fold milking (I and II milking - 180 cows). The interval between milking at a 3-fold milking was about 6 hours, with a 2-fold milking - about 12 hours. Milk sampling was carried out monthly, individually from each cow, when milking was performed in accordance with the physiological state of the cows, milking of cows was carried out 3 times in the first 100 days of lactation, in the subsequent days of lactation - 2-fold. The average annual dairy productivity of cows is 6.2-6.8 thousand $\mathrm{kg}$ of milk for standard lactation, the age of cows is within 3-8 years, the inter-hospital period, as a rule, does not exceed 400 days. After the selection, samples of milk in a refrigerated state (up to $+80{ }^{\circ} \mathrm{C}$ ) were delivered by a specialized motor vehicle to the Laboratory of Selection Quality of Milk of FSBEI HE Stavropol State University where the main parameters of milk were studied: fat, protein. Determination of milk fat and milk protein were carried out instrumentally using the MilkoScan MARS 6 analyzer (FOSS, Denmark), which uses infrared technology to determine concentrations of the studied parameters. The milk samples were studied in 2 replicates, which used the mean value, the error of the studies does not exceed the error of the instrument $( \pm 1.2 \%)$.

The work was carried out in accordance with Russian regulatory requirements and taking into account the recommendations of the International Committee for Registration of Animals (ICAR) (Global Standard..., 2017).

\section{RESULTS OF THE RESEARCH}

Analysis of the monitoring of daily values of fat and protein (Table 1) shows that the dynamics of these parameters for 2 and 3 -fold milking is somewhat different.

In the absence of a statistically significant difference between the mean daily parameters ( $p>0.05)$, nevertheless, at 2-fold milking, the parameters of evening milking are $4.1 \%$ higher, than at 3 -fold $(p<0.05)$, although the explanation for this is certainly the different character of milk formation in the udder of cows at 2 and 3-fold milking. Changes in protein content in milk during milking are much less variable, compared with the variability of fat. So, if the concentration

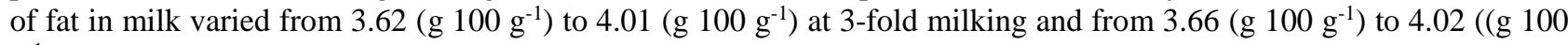
$\left.\mathrm{g}^{-1}\right)$, which was $10.77-10.98 \%$, then the indications of protein concentration in milk varied in the range

Table 1. Results of daily monitoring of fat and protein in milk

\begin{tabular}{|c|c|c|c|c|c|}
\hline \multicolumn{2}{|c|}{ Indicator } & 3-fold milking & $\%$ of daily average data & 2-fold milking & $\%$ of daily average data \\
\hline \multirow{2}{*}{$\begin{array}{l}\text { Average daily } \\
\text { diets }\end{array}$} & Fat, g $100 \mathrm{~g}^{-1}$ & $3.78 \pm 0.02$ & 100.00 & $3.81 \pm 0.03$ & 100.00 \\
\hline & Protein, g $100 \mathrm{~g}^{-1}$ & $3.42 \pm 0.02$ & 100.00 & $3.44 \pm 0.03$ & 100.00 \\
\hline \multirow[t]{2}{*}{ I milking } & Fat, g $100 \mathrm{~g}^{-1}$ & $3.62 \pm 0.03$ & 95.82 & $3.66 \pm 0.03$ & 96.09 \\
\hline & Protein, g $100 \mathrm{~g}^{-1}$ & $3.41 \pm 0.02$ & 99.70 & $3.42 \pm 0.03$ & 99.43 \\
\hline \multirow[t]{2}{*}{ II milking } & Fat, g $100 \mathrm{~g}^{-1}$ & $4.01 \pm 0.03$ & 106.02 & - & - \\
\hline & Protein, g $100 \mathrm{~g}^{-1}$ & $3.44 \pm 0.02$ & 100.50 & - & - \\
\hline \multirow[t]{2}{*}{ III milking } & Fat g $100 \mathrm{~g}^{-1}$ & $3.86 \pm 0.02$ & 102.12 & $4.02 \pm 0.03$ & 105.73 \\
\hline & Protein, g $100 \mathrm{~g}^{-1}$ & $3.42 \pm 0.02$ & 100.09 & $3.45 \pm 0.03$ & 100.28 \\
\hline
\end{tabular}

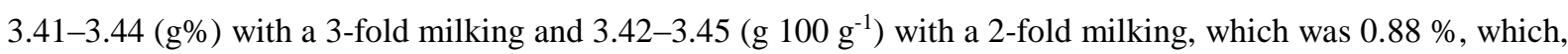
on the whole, coincides with the studies of other authors (Global Standard..., 2017).

The graphical representation of the daily dynamics of fat in milk clearly shows the nature of the change in the concentration of this indicator, the fat in milk at I milking is always lower, similar indicators for II and III milking (Figure 1). 


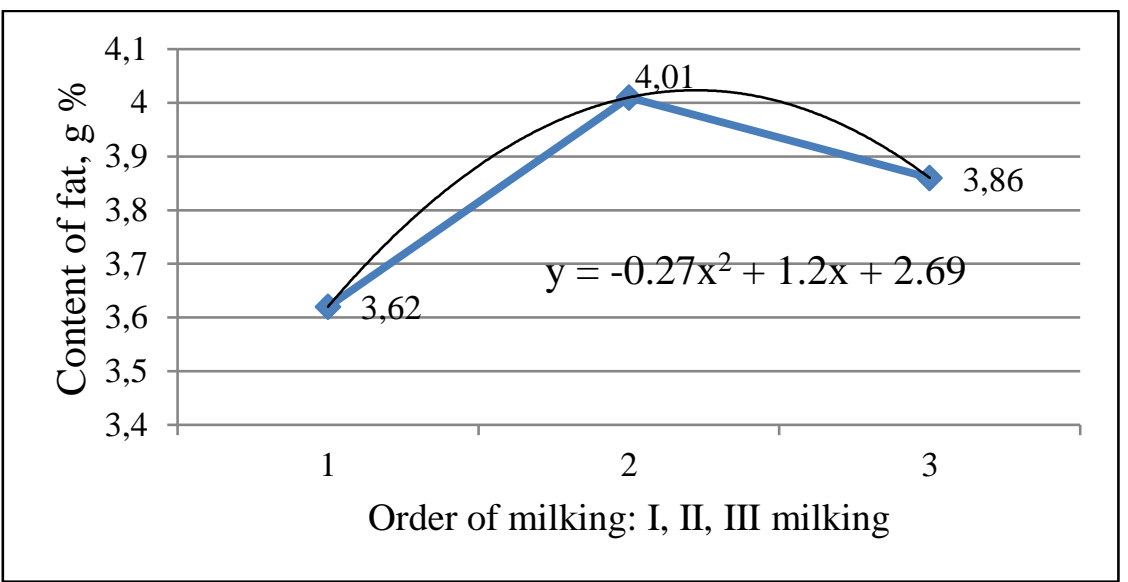

Figure 1. Daily dynamics of fat with a 3-fold milking of cows

The nature of the daily dynamics of fat in milk is most fully described by a power-law mathematical regression equation, using which you can predict changes in fat in milk for a day.

A study of the daily dynamics of fat in milk with 2-fold milking shows that the nature of the relationship between fat content in milk and the order of milking has a linear mathematical form, that is, in milk from milking I the fat content is always lower than in milk from milking II.

The nature of the daily dynamics of protein content in milk largely similar nature of the dynamics of fat in the milk (Fig. 1, 2 and 3), although the variability of the feature in this case is much lower compared to the fat and is $0.88 \%$. It should also be noted that these features are characteristic of cows in terms of a balanced ration in which the ratio of fat to protein in milk is in the range of 1.1 to 1.5 .

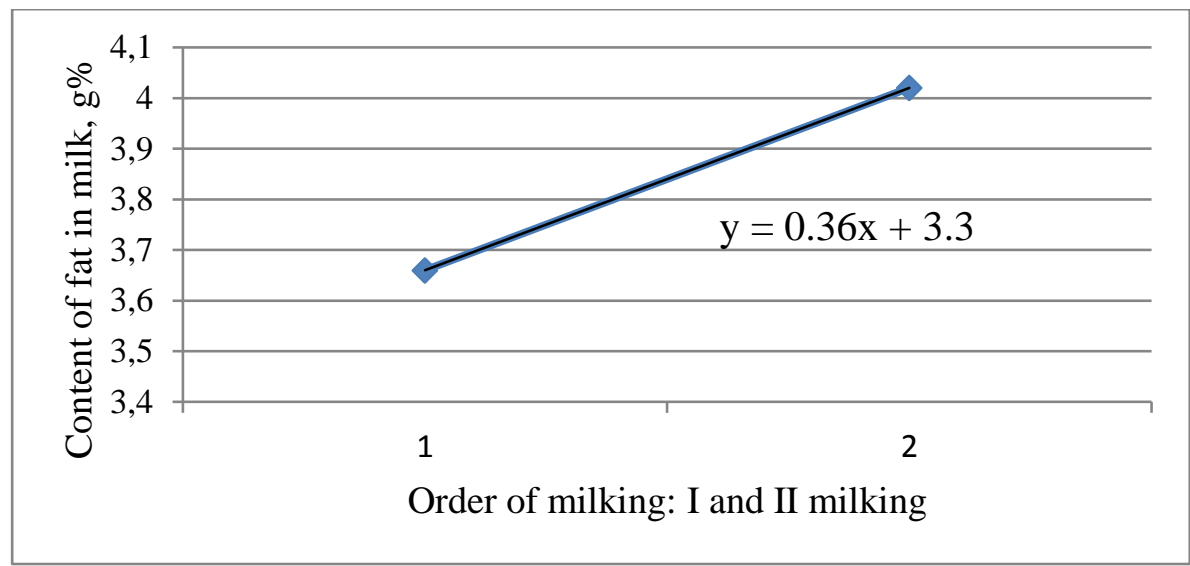

Figure 2. Daily dynamics of fat in milk with 2-fold milking

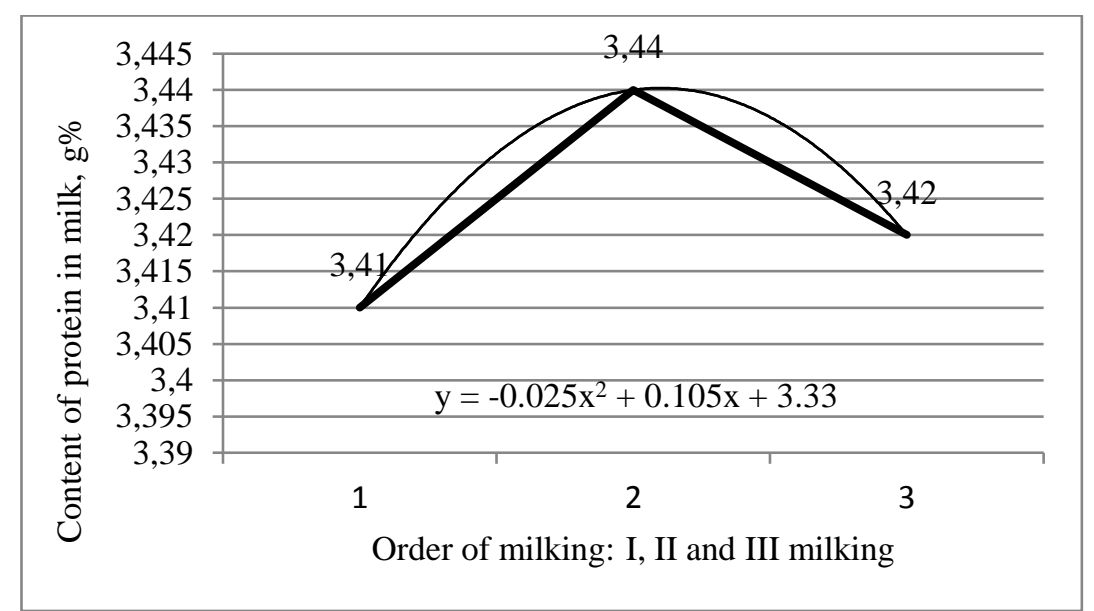

Figure 3. Daily dynamics of protein in milk with 3-fold milking

The use of regularities in the biological synthesis of milk components makes it possible to plan the nature and directions of the use of raw milk obtained from various milking plants. For example, milk from morning milking is likely to be used to make milk drinks, and milk obtained from II and III milking can be used to make dairy products with a high fat content, for example cheese, butter. 
Using these regularities of the dynamics of concentration of the main components of milk, it is possible to correctly organize the management of the dairy herd and improve the efficiency of dairy cattle.

\section{CONCLUSIONS}

1. The dynamics of fat concentration in milk at 2- and 3-fold milking has, though a different mathematical form, but they have a general tendency: the fat in milk for milking cows, as a rule, is $10.77-10.98 \%$ lower than II and III milking.

2. The dynamics of protein concentration in milk at 2- and 3-fold milking is the same as dynamics of fat in milk, though the variability of the concentration of protein in milk throughout the day is much less expressed than of fat and accounts $0.88 \%$.

\section{REFERENCES}

1. Bouloc, N.J. Delacroi, V. Dervishi. 2002. Milk recording and automatic milking systems: features and simplification possibilities of recording procedures. Presented at the 33th biennial Session of ICAR, Interlaken, Switzerland, May 26-31, 2002.

2. Delorenzo, M.A., and G.R.Wiggans. 1986. Factors for estimating daily yield of milk, fat, and protein from a single milking for herds milked twice a day. Journal of Dairy Science, Vol. 69. Iss. 9, pp. 2386-2394. https://doi.org/10.3168/jds.S00220302(86)80678-6

3. Global Standard for Livestock Data. 2017. Procedure 1 of Section 2 of ICAR Guidelines - Computing 24-hour Yields, Version October, 2017. http://www.icar.org/Guidelines/02-Procedure-1-Computing-24-Hour-Yield.pdf

4. Hand K. J., Lazenby D., Miglior F. and Kelton D.F. 2004. Comparison of Protocols to Estimate 24 Hour Percent Fat and Protein. Proceedings of the 34th ICAR Meeting EAAP Publication No. 113, pp. 219-224.

5. Hand K. J., Lazenby D., Miglior F. and Kelton D. F. 2006. Comparison of Protocols to Estimate Twenty-Four-Hour Fat and Protein Percentages for Herds with a Robotic Milking System. Journal of Dairy Science, Vol. 89, pp. $1723-1726$. https://doi.org/10.3168/jds.S0022-0302(06)72240-8

6. Lazenby, D., Bohlsen, E., Hand, K.J., Kelton, D.F., Miglior, F., Lissemore, K.D. 2002. Methods to estimate 24-hour yields for milk, fat and protein in robotic milking herds. Presented at the 33th biennial Session of ICAR, Interlaken, Switzerland, May 26$31,2002$.

7. Liu, Z., R. Reents, F. Reinhardt and K. Kuwan. 2000. Approaches to Estimating Daily Yield from Single Milk Testing Schemes and Use of a.m.-p.m. Records in Test-Day Model Genetic Evaluation in Dairy Cattle. Journal of Dairy Science, Vol. 83, pp. 2672-2682. https://doi.org/10.3168/jds.S0022-0302(00)75161-7

8. Peeters, R., Galesloot, P.J.B. 2002. Estimating Daily Fat Yield from a Single Milking on Test Day for Herds with a Robotic Milking System. Journal of Dairy Science, Vol. 85, Iss. 3, pp. 682-8. https://doi.org/10.3168/jds.S0022-0302(02)74124-6

9. Trukhachev, V.I, Zlydnev, N.Z., Oleinik, S.A. 2015. Ways to improve the efficiency of milk production in the Stavropol region. Business Bulletin of the AIC. Stavropol region, No. 12, pp. 57-60.

10. Trukhachev, V.I, Oleinik S.A., Zlydnev, N.Z. 2017. Model of Genetics Management. Information Bulletin of the Ministry of Agriculture of the Russian Federation, No 2, pp. 14-16.

11. Trukhachev, V.I., Oleinik, S.A, Zlydnev, N.Z. Morozov, V.Yu. 2016. Organization of regional selection and technology center for dairy cattle breeding, taking into account the requirements of the International Committee for Registration of Animals (ICAR). Agrus, Stavropol. 84 p. 